\title{
Carrier detection of Hunter syndrome (MPS II) by biochemical and DNA techniques in families at risk
}

\begin{abstract}
Winnie Schröder, Lothar Petruschka, Manfred Wehnert, Marlies Zschiesche,
\end{abstract} Günther Seidlitz, John J Hopwood, Falko H Herrmann

\begin{abstract}
DNA based and biochemical diagnosis of MPS II was performed on 13 unrelated families using Southern blotting. The ${ }^{35} \mathrm{~S}$-sulphate accumulation in cultured fibroblasts was investigated and the iduronate-2-sulphatase (IDS) activity in the serum determined. Sixteen patients and $\mathbf{3 6}$ females at risk were screened for structural aberrations and by RFLP analysis using the intragenic probe pc2S15 and probes VK23B, VK21A, and II10 for the flanking loci DXS297, DXS296, and DXS466. Structural alterations were found in the DNA of two patients. One of them showed a major deletion including the whole coding sequence of the IDS gene. An aberrant Southern fragment occurred in the HindIII/pc2S15 blot of the other patient suggesting a new HindIII restriction site by point mutation in an IDS gene intron. Twenty-nine females were confirmed as carriers, and for five women the heterozygous state could be excluded. Prenatal diagnosis can be offered to 27 women if requested. ( $\mathcal{F}$ Med Genet 1993;30:210-13)
\end{abstract}

A deficiency in the activity of the iduronate-2sulphatase (IDS) gene leads to lysosomal accumulation of heparan and dermatan sulphate fragments, their excretion in urine, and to phenotypic expression of MPS II (Hunter syndrome). ${ }^{1}$ The incidence of the disease has been established to be between 7.5 and 14.8 per million male live births. ${ }^{2}$ Clinically, the patients may present a wide spectrum of phenotypes. In severely affected patients the lysosomal accumulatio:-1 of glycosaminoglycans causes progressive damage to the brain, liver, and other organs and severe motor retardation, and leads to death before adulthood. Patients with mild forms survive with little or no mental retardation but frequently suffer bone malformations.

Owing to the $\mathrm{X}$ linked recessive inheritance, ${ }^{34}$ females of MPS II families are at risk of being carriers of the disorder. So far, carrier detection tests have been made by analysing enzyme (IDS) activity in serum or fibroblasts and by measuring the ${ }^{35} \mathrm{~S}$-sulphate accumulation in cultured fibroblasts in the presence of fructose-1-phosphate (F-1-p). ${ }^{5-7}$ Owing to $X$ chromosome inactivation in females only about $90 \%$ of the carriers can be detected by these methods. The isolation of an IDS
$\mathrm{cDNA}^{8}$ and the description of intragenic and extragenic RFLPs near the IDS locus ${ }^{4-11}$ makes possible the investigation of MPS II families by intra- and extragenic RFLP analysis.

We describe the results of Southern analysis in 13 unrelated families with MPS II and compare these results with the data obtained by biochemical carrier detection tests.

\section{Methods}

The IDS activity in serum and fibroblasts was determined with the natural substrate $(\mathrm{L}-O$-( $\alpha$-iduronic acid 2 -sulphate)-( $1 \rightarrow 4)-\mathrm{D}$ $O-2,5$-anhydro[ $\left[1-{ }^{3} \mathrm{H}\right]$ mannitol 6 -sulphate) by a modification of the method of Archer et al. ${ }^{5}$ The ${ }^{35} \mathrm{~S}$-sulphate accumulation in cultured cells in the presence of $F-1-p$ was measured as described by Petruschka et al.$^{12}$ By this method the presence of cells expressing the deficient phenotype was indicated by the increased ratio $(F+/ F-)$ of sulphate incorporation by cells cultured with or without F-1-p and an increased difference $(\Delta)$ in the accumulation factors between these cultures (table 1).

Genomic DNA for the Southern analyses was prepared by standard methods from peripheral white blood cells or fibroblast cultures of patients and women at risk $^{1314} ; 10 \mu \mathrm{g}$ of genomic DNA was completely digested by the appropriate restriction enzymes (AGS, Boehringer Mannheim). After agarose gel electrophoresis, DNA was transferred onto nitrocellulose filters (Amersham). DNA probes were radiolabelled with deoxycytidine ${ }^{32} \mathrm{P}$-phosphate using an oligolabelling kit (Amersham/Buchler), and hybridisation was performed at $42^{\circ} \mathrm{C}$ in the formamide system as previously described. ${ }^{15}$

For the genomic diagnosis of MPS II families we used the intragenic probe pc2S15 $(S t u \mathrm{I} / \mathrm{pc} 2 \mathrm{~S} 15)$ and the flanking probes VK23B, VK21A, and II-10 (XmnI/VK23B, TaqI/VK21A, TaqI/II-10). For deletion screening the additional probe VK18 (DXS295) was used..$^{41011}$

\section{Results}

The diagnosis of MPS II was confirmed by enzyme analysis in 18 families of German origin. The families were investigated by biochemical methods and counselled by offering prenatal diagnosis for the women at risk. ${ }^{12}$ The figure shows examples of the pedigrees of 
Table 1 Results of carrier detection by biochemical tests and genomic analysis in obligate carriers for MPS II.

\begin{tabular}{|c|c|c|c|c|}
\hline \multirow[b]{2}{*}{ Pedigree No } & \multicolumn{2}{|c|}{ F-1-p test } & \multirow[b]{2}{*}{ IDS-activity } & \multirow[b]{2}{*}{ DNA } \\
\hline & $\Delta$ & $\mathrm{F}+/ \mathrm{F}-$ & & \\
\hline $\begin{array}{l}\text { Family } 1 \\
\text { I } \cdot 1 \\
\text { II } \cdot 1 \\
\text { II } \cdot 3 \\
\text { II } \cdot 10\end{array}$ & $\begin{array}{l}3 \cdot 31 \\
1.20 \\
0 \cdot 6 \\
1 \cdot 7\end{array}$ & $\begin{array}{l}4 \cdot 17 \\
1.85 \\
1.66 \\
1.84\end{array}$ & $\begin{array}{l}0.047 \\
0.043 \\
0.094 \\
0.091\end{array}$ & $\begin{array}{l}\mathrm{NI} \\
\mathrm{HZ} \\
\mathrm{HZ} \\
\mathrm{ND}\end{array}$ \\
\hline $\begin{array}{l}\text { Family } 2 \\
\text { I } \cdot 2 \\
\text { II } \cdot 2 \\
\text { II } \cdot 4\end{array}$ & $\begin{array}{l}1 \cdot 67 \\
4.88 \\
1.60\end{array}$ & $\begin{array}{l}2 \cdot 67 \\
4 \cdot 25 \\
2 \cdot 71\end{array}$ & $\begin{array}{l}0.045 \\
0.06 \\
0.095\end{array}$ & $\begin{array}{l}\mathrm{NI} \\
\mathrm{HZ} \\
\mathrm{ND}\end{array}$ \\
\hline $\begin{array}{l}\text { Family } 3 \\
\text { I } 11 \\
\text { II } 6 \\
\text { II } \cdot 10\end{array}$ & $\begin{array}{l}0 \cdot 38 \\
4 \cdot 29 \\
4 \cdot 77\end{array}$ & $\begin{array}{l}1 \cdot 50 \\
2 \cdot 06 \\
2 \cdot 44\end{array}$ & $\begin{array}{l}0.07 \\
\text { ND } \\
0.045\end{array}$ & $\begin{array}{l}\mathrm{HZ} \\
\mathrm{HZ} \\
\mathrm{HZ}\end{array}$ \\
\hline $\begin{array}{l}\text { Family } 4 \\
\text { I } \cdot 2 \\
\text { II } \cdot 4\end{array}$ & $\begin{array}{l}2 \cdot 44 \\
5 \cdot 88\end{array}$ & $\begin{array}{l}2 \cdot 29 \\
3 \cdot 14\end{array}$ & $\begin{array}{l}0.067 \\
0.045\end{array}$ & $\begin{array}{l}\mathrm{NI} \\
\mathrm{HZ}\end{array}$ \\
\hline $\begin{array}{l}\text { Family } 5 \\
\text { II }\end{array}$ & & & $0 \cdot 16$ & ND \\
\hline $\begin{array}{l}\text { Family } 6 \\
\text { I.2 }\end{array}$ & $8 \cdot 65$ & $2 \cdot 24$ & ND & ND \\
\hline $\begin{array}{l}\text { Family } 7 \\
\text { II } 44\end{array}$ & 3.01 & $2 \cdot 46$ & 0.057 & $\mathrm{HZ}$ \\
\hline $\begin{array}{l}\text { Family } 11 \\
\text { II } 2\end{array}$ & $0 \cdot 7$ & $3 \cdot 0$ & ND & $\mathrm{HZ}$ \\
\hline $\begin{array}{l}\text { Family } 13 \\
\mathbf{I} \cdot 2\end{array}$ & $2 \cdot 8$ & $2 \cdot 0$ & ND & $\mathrm{HZ}$ \\
\hline $\begin{array}{l}\text { Family } 14 \\
\text { II } 2\end{array}$ & ND & ND & 0.05 & ND \\
\hline $\begin{array}{l}\text { Normal controls } \\
\mathrm{x} \pm \mathrm{s} \\
\mathrm{N} \\
\text { Cut off }\end{array}$ & $\begin{array}{c}0.03 \\
\pm 0.17 \\
11 \\
0.5\end{array}$ & $\begin{array}{c}0.86 \\
\pm 0.34 \\
15 \\
1.5\end{array}$ & $\begin{array}{c}0.216 \\
\pm 0 \cdot 19 \\
20 \\
0 \cdot 1\end{array}$ & \\
\hline
\end{tabular}

$\mathrm{NI}=$ not informative. $\mathrm{ND}=$ not determined. $\mathrm{HZ}=$ heterozygote for one or more RFLPs.

MPS II families with the results of pedigree, biochemical, and molecular analysis. In 13 families which we investigated extensively, 18 females were obligate carriers for the MPS II gene. The results of the different carrier detection tests, namely IDS activity in serum, sulphate incorporation in cultured skin fibroblasts, and RFLP analysis, are summarised in table 1 .

Although the enzyme activity in the serum of MPS carriers is about $50 \%$ or less compared with the average IDS activity in the serum of healthy persons, there is a broad overlap in the range of specific activities. A cutoff limit of 0.5 for $\Delta$ and of 1.5 for the ratio $F+/ F-$ was fixed for the sulphate accumulation test. Only one (family $3, \mathrm{I} \cdot 1$ ) of the 16 obligate carriers investigated by this method gave an ambiguous result.

Thirty-six females, including the 18 obligate carriers, were investigated by DNA based analysis. Of the 18 potential carriers, 11 were proven to be heterozygous for the MPS II gene and in five women the heterozygous state could be excluded. In two cases RFLP analysis was not informative. These results agree well with those of the biochemical carrier detection tests. As a result of these investigations DNA based prenatal diagnosis could be offered to 27 women (14 of them with the intragenic StuI/ pc2S15 RFLP) (table 2).

We found structural aberrations in only two of the 16 patients. ${ }^{1617}$ One patient was found to have a major deletion including the entire coding region and the extragenic locus DXS466 (table 3). In another patient a normal
$9.4 \mathrm{~kb}$ fragment disappeared while an aberrant fragment of $3.5 \mathrm{~kb}$ occurred in the HindIII/ pc2S15 blot. Normal Southern patterns occurred in the Pst I and $T a q \mathrm{I} / \mathrm{pc} 2 \mathrm{~S} 15$ blots suggesting a new HindIII restriction site by point mutation in an IDS gene intron. This marker fragment was also detected in the Southern blot of the mother.

\section{Discussion}

The detection of female carriers by enzymatic methods is sometimes equivocal owing to the wide range of enzyme activity in the serum of normal or heterozygous females. According to our experience and to results published by others, ${ }^{18}$ about $10 \%$ of false positive or negative results can be assumed for this test. The sulphate accumulation test produces a more accurate diagnosis. So far no false positive results have been reported ${ }^{19}$ (L Petruschka, unpublished data), but even with this method about $10 \%$ of potential carriers cannot be detected.

The molecular characterisation of a specific mutation in a patient would allow direct segregation analysis of this defect in the family. Using Southern blotting for deletion screening we found only one deletion in 13 families. The suggested new HindIII restriction site in patient G-117 is localised in the $9.4 \mathrm{~kb}$ fragment of the IDS structural gene and should result in two smaller fragments. A $3.5 \mathrm{~kb}$ fragment containing exon sequences can be detected by the IDS cDNA. The second expected fragment of $5.9 \mathrm{~kb}$ contains only intron sequences and was therefore not detectable by the cDNA probe used. The aberrant fragment can be detected in the Southern blot of the patient's mother as well, so it can be used as a direct intragenic segregation marker for MPS II in this family.

In most cases the molecular defect cannot be detected by Southern blotting. The method generally followed for DNA based diagnosis in such families is gene tracking using intragenic and intergenic RFLPs closely linked to the mutation site. The reliability of this indirect genotype analysis is dependent on the crossover rate between the mutation and RFLP sites.

Using the intragenic marker StuI/pc2S15 the error rate caused by recombination should be less than $1 \%$. Recombination fractions between the IDS locus and flanking loci were determined by multipoint analysis. ${ }^{49}$ No recombination was observed between the IDS locus and the flanking loci DXS296 or DXS466.

The results of the DNA based diagnosis in MPS II families show good agreement with the results of the biochemical diagnosis. About $90 \%$ of females are informative for one or more RFLPs and $50 \%$ of them are informative for the intragenic RFLP and another $10 \%$ for the closely linked intergenic $T a q \mathrm{I} / \mathrm{VK} 21 \mathrm{~A}$ or TaqI/II-10 RFLPs or both.

At present, the use of the intragenic IDS cDNA probes and flanking probes available so far allows carrier detection in MPS II families 

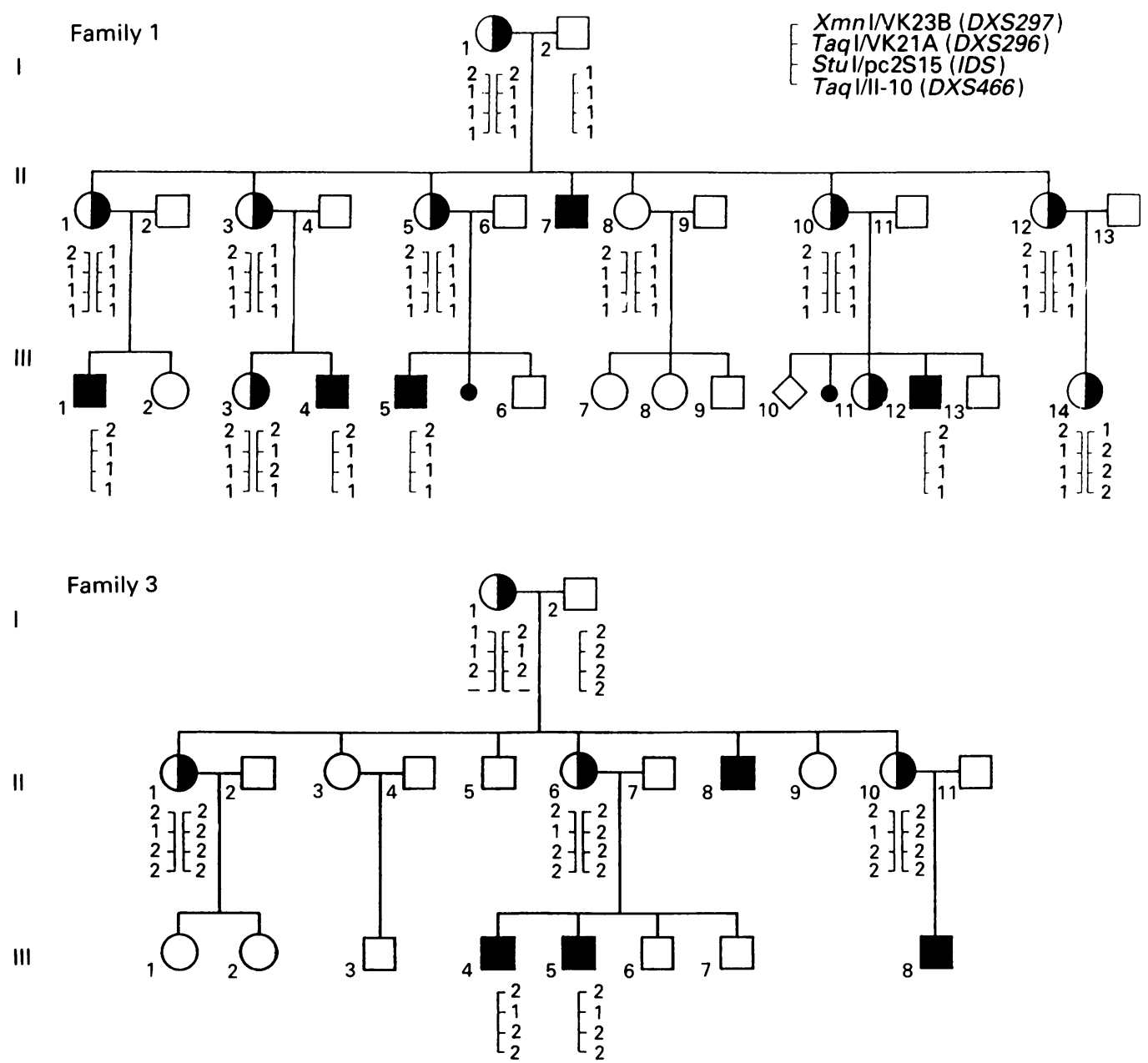

Affected male

Carrier female

Segregation analysis in two families at risk for MPS II for carrier detection using one intragenic and three extragenic RFLPs. The carrier status was confirmed by biochemical and genomic diagnosis.

Table 2 Heterozygosity of intragenic and intergenic RFLP of the IDS gene in female heterozygotes for $M P S I I$.

\begin{tabular}{lccc}
\hline & $\begin{array}{c}\text { Informative } \\
\text { genotypes }\end{array}$ & $\begin{array}{c}\text { Total No } \\
\text { of probands }\end{array}$ & $\begin{array}{c}\text { Heterozygosity } \\
\text { found in the } \\
\text { population } \\
(\%)\end{array}$ \\
RFLP & 14 & 28 & 50 \\
StuI/pc2S15 & 14 & 22 & 64 \\
XmnI/Vk23B & 4 & 22 & 18 \\
TaqI/Vk21A & 6 & 27 & 22 \\
TaqI/II-10 & & & \\
StuI/pc2S15 & 18 & 29 & 62 \\
+ TaqI/Vk21A & & & \\
StuI/pc2S15 & & & \\
+ XmnI/Vk23B & & 29 & \\
+ TaqI/Vk21A & & & \\
+ TaqI/II-10 & 27 & & \\
\hline
\end{tabular}

Table 3 Deletion screening in patient G-65.

\begin{tabular}{lccccc}
\hline Probe & VK23B & VK21A & VK18A & IDS & II-10 \\
Locus & $D S X 297$ & $D X S 296$ & $D X S 295$ & $p c 2 S 15$ & $D X S 466$ \\
\hline Patient G-65 & + & + & + & - & - \\
\hline
\end{tabular}

with the same accuracy as, or a little more than, the investigation of IDS activity in serum or of sulphate accumulation in cultured cells. Although genomic analysis will be the method of choice in the future, the application of biochemical methods to carrier detection may be helpful in selected cases.

We are grateful to Dr G R Sutherland, Adelaide, for providing the probes VK21A, VK23B, and VK18 and to Dr T Hulseboes, Amsterdam, for providing the probe II- 10 . This work was supported by a grant from Deutsche Forschungsgemeinschaft No $\mathrm{He}$ 1885/1-1.

1 Neufeld EF, Muenzer J. The mucopolysaccharidoses. In Scriver CR, Beaudet MC, Sly WS, Valle D, eds. The metabolic basis of inherited disease. 6th ed. New York: McGraw-Hill: 1989:1565-87.

2 Machill G, Barbujani G, Danieli GA, Herrmann FH Segregation and sporadic cases in families with Hunter's ened Genet 1991;28:398-401

3 Thomas NST, Roberts SH, Upadhyaya M, Knight S, Harper PS. Physical localization of the X:autosomal ranslocation breakpoint from a girl expressing Hunter syndrome using Xq27-Xq28 markers. HGM 1989;10:2620A.

4 Suthers GK, Oberlé I, Nancarrow J, et al. Genetic mapping of new RFLPs at Xq27-q28. Genomics 1991;9:37-43.

5 Archer IM, Harper PS, Wusteman FS. An improved assay for iduronate 2-sulfatase in serum and its use in the detection of carriers of the Hunter syndrome. Clin Chim Acta 1981;112:107-12. 
6 Tønnesen T, Lykkelund C, Güttler F. Diagnosis of Hunter's syndrome carriers; radioactive sulphate incor-
poration into fibroblasts in the presence of fructose 1poration into fibroblasts in the presen
phosphate. Hum Genet 1982;60:167-71.

7 Petruschka L, Machill G, Wehnert M, Seidlitz G, Knapp A. Reliability of the Tonnesen technique for the identification of Hunter carriers. Hum Genet 1983;64:404-6.

8 Wilson PJ, Morris CP, Anson DS, et al. Hunter syndrome: isolation of an iduronate-2-sulfatase cDNA clone and analysis of patient DNA. Proc Natl Acad Sci USA 1990;87:8531-5.

9 Suthers GK, Mulley JC, Voelkel MA, et al. Genetic mapping of new DNA probes at Xq27 defines a strategy for DNA studies in the fragile $\mathrm{X}$ syndrome. Am $\mathcal{F}$ Hum Genet 1991;48:460-7.

10 Yu S, Suthers GK, Mulley JC. A Bc1I RFLP for DXS296 (VK21) near fragile X. Nucleic Acids Res 1990;18:690.

11 Hulseboes TJM, Oostra BA, Broersen S, Smits A, van Oost BA, Westerveld A. New distal marker closely linked to
the fragile X locus. Hum Genet 1991;87:369-72.

12 Petruschka L, Seidlitz G, Machill G. Familienuntersuchungen bei Mucopolysaccharidose Typ II (Morbus suchungen bei Mucopolysaccharidose Typ II (Morbus
Hunter). Wiss $Z$ Ernst-Moritz-Arndt-Univ Greifswald, Med Reine 1988;37:23-7.
13 Southern E. Detection of specific sequences among DNA fragments separated by gel electrophoresis. $f$ Mol Biol 1975;98:503-17.

14 Herrmann FH, WJulff K, Schütz M, Wehnert M. Deletion screening and prenatal diagnosis of Duchenne muscular dystrophy using cDNA probed Cf $23 \mathrm{a}$ and Cf $56 \mathrm{a}$. Eur $\mathcal{F}$ Pediatr 1990;149:263-5.

15 Davies KE, Speer A, Herrmann FH, et al. Human Xchromosome markers and Duchenne muscular dystrophy. Nucleic Acids Res 1985;13:3419-26.

16 Wehnert M, Hopwood JJ, Schröder W, Herrmann FH Structural gene aberrations in mucopolysaccaridosis II (Hunter). Hum Genet 1992;89:430-2.

17 Herrmann FH, Hopwood JJ, Schröder W, Wehnert M Molecular aberrations in patients of iduronate-2-sulfatesulfatase defect (MPSII Hunter). Cytogenet Cell Genet 1991;58:2066.

18 Zlotogora J, Bach G. Heterozygote detection in Hunter syndrome. Am $\mathcal{F}$ Med Genet 1984;17:661-5.

19 Tonnesen T. The use of fructose 1-phosphate to detect Hunter heterozygotes in fibroblast cultures from highrisk carriers. Hum Genet 1984;66:212-6. 